\title{
Local and regional smoke impacts from prescribed fires
}

\author{
Owen F. Price ${ }^{1}$, Bronwyn Horsey ${ }^{1}$, and Ningbo Jiang ${ }^{2}$ \\ ${ }^{1}$ Centre for Environmental Risk Management of Bushfires, University of Wollongong, Wollongong, NSW 2522, Australia \\ ${ }^{2}$ Climate and Atmospheric Science Branch, Office of Environment and Heritage, Sydney, NSW 2141, Australia
}

Correspondence to: Owen F. Price (oprice@uow.edu.au)

Received: 26 February 2016 - Published in Nat. Hazards Earth Syst. Sci. Discuss.: 22 March 2016

Revised: 5 September 2016 - Accepted: 6 September 2016 - Published: 14 October 2016

\begin{abstract}
Smoke from wildfires poses a significant threat to affected communities. Prescribed burning is conducted to reduce the extent and potential damage of wildfires, but produces its own smoke threat. Planners of prescribed fires model the likely dispersion of smoke to help manage the impacts on local communities. Significant uncertainty remains about the actual smoke impact from prescribed fires, especially near the fire, and the accuracy of smoke dispersal models.

To address this uncertainty, a detailed study of smoke dispersal was conducted for one small (52 ha) and one large (700 ha) prescribed fire near Appin in New South Wales, Australia, through the use of stationary and handheld pollution monitors, visual observations and rain radar data, and by comparing observations to predictions from an atmospheric dispersion model. The 52 ha fire produced a smoke plume about $800 \mathrm{~m}$ high and $9 \mathrm{~km}$ long. Particle concentrations $\left(\mathrm{PM}_{2.5}\right)$ reached very high peak values $\left(>400 \mu \mathrm{g} \mathrm{m}^{-3}\right)$ and high $24 \mathrm{~h}$ average values $\left(>100 \mathrm{\mu g} \mathrm{m}^{-3}\right)$ at several locations next to or within $\sim 500 \mathrm{~m}$ downwind from the fire, but low levels elsewhere. The 700 ha fire produced a much larger plume, peaking at $\sim 2000 \mathrm{~m}$ altitude and affecting downwind areas up to $14 \mathrm{~km}$ away. Both peak and $24 \mathrm{~h}$ average $\mathrm{PM}_{2.5}$ values near the fire were lower than for the 52 ha fire, but this may be because the monitoring locations were further away from the fire. Some lofted smoke spread north against the ground-level wind direction. Smoke from this fire collapsed to the ground during the night at different times in different locations. Although it is hard to attribute particle concentrations definitively to smoke, it seems that the collapsed plume affected a huge area including the towns of Wollongong, Bargo, Oakdale, Camden and Campbelltown $\left(\sim 1200 \mathrm{~km}^{2}\right)$. $\mathrm{PM}_{2.5}$ concentrations up to $169 \mu \mathrm{g} \mathrm{m}^{-3}$ were recorded on the morning following the fire. The atmospheric
\end{abstract}

dispersion model accurately predicted the general behaviour of both plumes in the early phases of the fires, but was poor at predicting fine-scale variation in particulate concentrations (e.g. places $500 \mathrm{~m}$ from the fire). The correlation between predicted and observed varied between 0 and 0.87 depending on location. The model also completely failed to predict the night-time collapse of the plume from the 700 ha fire.

This study provides a preliminary insight into the potential for large impacts from prescribed fire smoke to NSW communities and the need for increased accuracy in smoke dispersion modelling. More research is needed to better understand when and why such impacts might occur and provide better predictions of pollution risk.

\section{Introduction}

Smoke from wildfire has caused pollution events in large Australian cities on many occasions. For example, the alpine fires in northeast Victoria in 2009 caused serious smoke pollution across Melbourne on several days over a period of a month (Tham et al., 2009). Pollution from wildfire is recognised as a health issue in Australia (Hanigan et al., 2008; Johnston et al., 2011) and globally (Sapkota et al., 2005; Jayachandran, 2009). As air pollution standard become stricter across Australia and steps are taken to reduce emissions from industrial and transport sources, so the relative contribution of wildfire smoke to total particulate matter becomes greater.

Prescribed burning is intended to reduce the risks to the community from unplanned fires. Primarily, this is focussed on reducing loss of life and damage to property. However, in terms of smoke pollution, there is a trade-off between the reduction of smoke from reduced wildfire activity resulting from prescribed burning treatment and the pollution from the 
prescribed fires themselves. The distribution of smoke impact from prescribed fires is likely to differ from that of wildfire. Wildfires are usually large with strong convective forces injecting smoke high into the atmosphere, which can lessen the impact to the local community, but can affect communities up to hundreds of kilometres away (Sapkota et al., 2005; Jayachandran, 2009). In comparison, the smoke from prescribed fires may linger near the fire. Also, wildfires are often located in remote areas such as national parks while prescribed fires are often located within or near the communities that fire management authorities intended to protect. This means that prescribed fires could have high local impacts.

While the potential hazard from prescribed fire smoke has been recognised (Haikerwal et al., 2015), most of our understanding of prescribed fire smoke exposure stems from research into wildfires (Reisen and Brown, 2009). There have been studies of firefighter exposure at prescribed fires (Miranda et al., 2010; Reisen et al., 2011; Adetona et al., 2013) but the effect of prescribed burning on smoke exposure to the local community has rarely been addressed in research (Reisen and Brown, 2009). To our knowledge there have only been two studies attempting to quantify the spatial distribution of prescribed burn smoke pollution close to the source (Pearce et al., 2012; Meyer et al., 2013), and only one of those was empirical (Pearce et al., 2012). Pearce et al. (2012) studied 55 prescribed fires at Savannah River (Georgia, USA) using a grid of pollution monitors and found that $\mathrm{PM}_{2.5}$ concentrations reduced to background levels within $2 \mathrm{~km}$ downwind of the fire (all other factors being equal).

Given the risks of smoke pollution affecting residents, many fire management agencies consider likely smoke impacts in their prescribed fires planning, using atmospheric dispersion models to predict the spread of particulate matter (PM) in the air. However, the use of dispersion models for predicting fire smoke is problematic because they are mostly designed to predict large-scale movements of pollutants (Pearce et al., 2012), with the exception of the VSMOKE model for line-of-sight modelling (Lavdas, 1996). Also the models are not well validated against observational data (Price et al., 2012).

Recent research on the effectiveness of prescribed burning has shown that over the long term it increases the total area burned in Australian eucalypt forests because approximately 3 ha of prescribed burning is required for every hectare reduction in wildfire area (Boer et al., 2009; Price and Bradstock, 2011; Bradstock et al., 2012). A similar increase in total area burnt due to prescribed burning is likely to occur in many regions globally (Price et al., 2015). However, this does not necessarily mean that the smoke impact is 3 times greater because less fuel is consumed in a prescribed fire. Nevertheless, the increased area burnt and the possibility for high local impact from prescribed fire smoke highlights the need to understand more about the dispersal of prescribed fire smoke.
This study measured the actual dispersal of prescribed fire smoke, primarily to determine the air quality impact on residents and the accuracy of the dispersion model prediction. Two prescribed fires were studied: one large (700 ha) and one small (52 ha). A mix of permanent, temporary fixed and handheld monitors were used to measure the temporal and spatial variation of the particle pollution at distance from within the fire perimeter to $30 \mathrm{~km}$ away. This was supplemented with measurement of the smoke plume via visual observation and 3-D rain radar data. The observations were compared to predictions from the TAPM atmospheric dispersion model (Hurley et al., 2005). Anecdotal evidence suggests that the local impact could be high and the accuracy of the model could be low for a variety of reasons. These include the following:

- The injection height is likely to be lower than assumed in the model, meaning most of the smoke will remain in the local area.

- Light winds favoured for prescribed burning also make the smoke linger.

- Temperature inversion during the night are common in the prescribed burning season, and this might increase pollutants at ground level long after the fire has ceased.

\section{Methods}

Two prescribed fires were observed in the field around the Cataract Scout Camp near Appin NSW (Figs. 1, 2). The vegetation around the camp is "Sydney coastal dry sclerophyll forest" (Keith, 2004) comprising a mix of eucalypt trees and shrubby understorey. The first fire was $52 \mathrm{ha}$, lit at 09:45 Australian eastern standard time (AEST, UTC $+10 \mathrm{~h}$ ) on $22 \mathrm{Au}-$ gust 2015, and targeted patches of forest within the scout camp. The second was 700 ha, lit at 10:15 Australian eastern daylight time (AEDT, UTC $+11 \mathrm{~h}$ ) on 9 October 2015 and burnt the area surrounding the camp in an arc from north through west to south. Pre-burn fuel assessments estimated the surface fuel load to be $15 \mathrm{tha}^{-1}$ and total fuel load to be 23 tha $^{-1}$ across the burn areas (S. Chadwick, personal communication, 2015).

A range of measurements were collected at the fire ground and surrounding areas:

1. Small monitoring stations were placed at two locations at the Scout Camp by the NSW Office of Environment and Heritage (OEH). The stations were within $50 \mathrm{~m}$ of burnt forest in the 52 ha fire but 220 and $800 \mathrm{~m}$ away from the 700 ha fire (Fig. 2). Each station was equipped with a variety of monitoring instruments, including a TEOM monitor (reference monitor hereafter) for measuring concentrations of $\mathrm{PM}_{2.5}$ (particulate matter less than $2.5 \mu \mathrm{m}$ in diameter). Reported $\mathrm{PM}_{2.5}$ values were $6 \mathrm{~min}$ averages. 


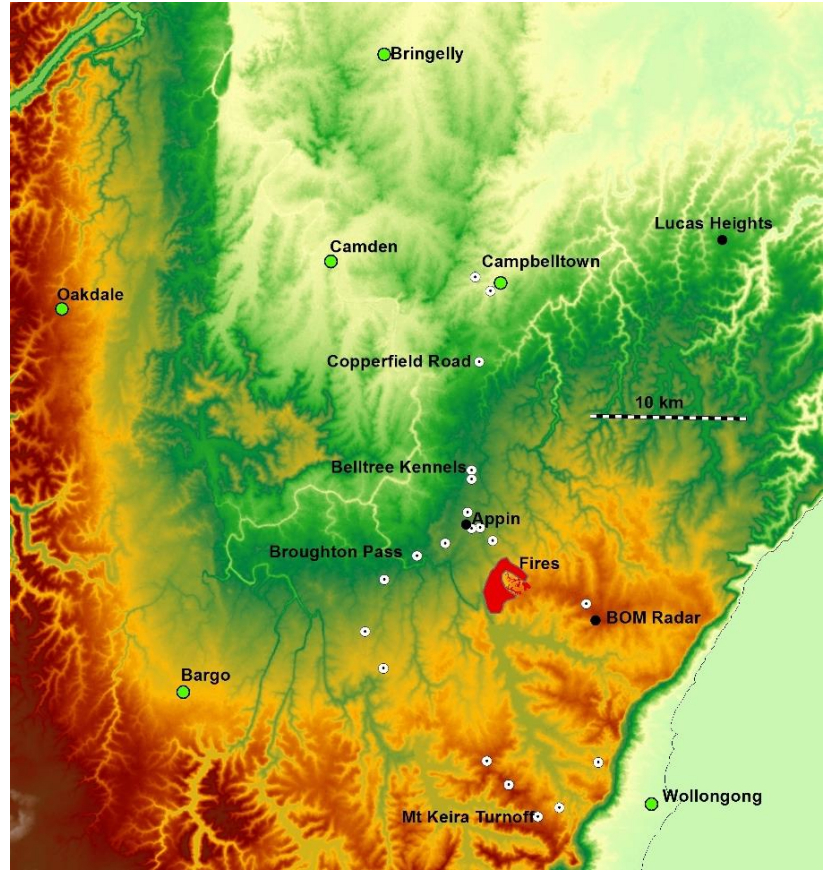

Figure 1. Location of the fires (red polygons) and relevant landmarks. Green dots are permanent air quality monitors; white dots are readings from handheld air quality monitor. Black dots are other landmarks. The background is elevation.

2. A handheld particle monitor (DustTrak II) was used to sample $\mathrm{PM}_{2.5}$ at a variety of locations around the outside of the fire, with distances ranging from $20 \mathrm{~m}$ to $18 \mathrm{~km}$ from the flames (Fig. 2). Six locations all within $1 \mathrm{~km}$ of the fires were sampled repeatedly approximately twice per hour, and more distant locations were sampled once or twice during the day. Due to the different areas burnt, most locations were closer to the 52 ha fire than the 700 ha fire (mean distance $332 \mathrm{~m}$ cf. $693 \mathrm{~m}$ ). Sampling was conducted until 18:00 local time of the burning day, with a single repeat measurement at $\sim$ 08:00 on the morning after the fire. Readings from the DustTrak II monitor were $1 \mathrm{~min}$ averages. For locations with several $\mathrm{PM}_{2.5}$ observations, peak and $24 \mathrm{~h}$ average (beginning at 10:00) values were estimated. In the case of the handheld monitor, only locations with three or more $\mathrm{PM}_{2.5}$ observations were used. The periods between observations were assumed to have the same value as that recorded before the fire commenced (a mean value of $4 \mu \mathrm{g} \mathrm{m}^{-3}$ ). This is a simple but conservative estimate of possible daily exposure.

3. The handheld monitor was calibrated against a reference monitor (TEOM) by taking 13 measurements next to the reference monitor, spread across the two fires and at different times of the day, and using linear regression to estimate the relationship between the two monitors.

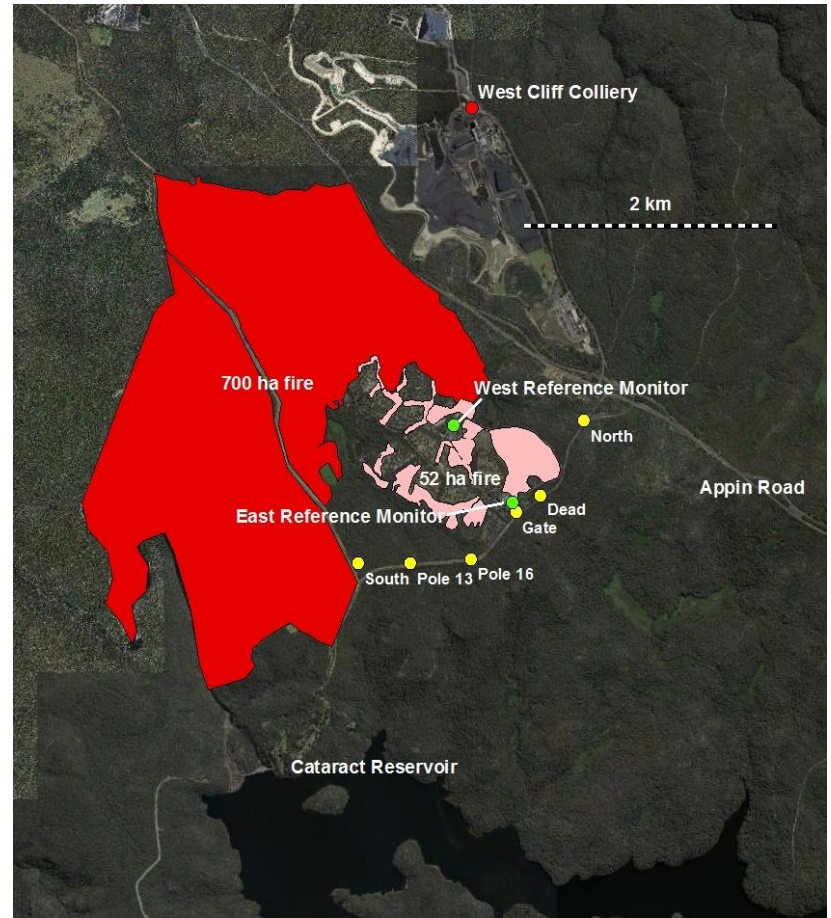

Figure 2. Detail of the fires and nearby air quality measurement locations. Green dots are reference air quality monitors; yellow dots are repeat measurements using the handheld air quality monitor. Red dots are other permanent monitors. The background is airphoto mosaic from Land and Property Information NSW.

4. For the period of the 700 ha fire, air quality data were also obtained from OEH for 11 long-term monitoring stations located in the Illawarra and Sydney metropolitan regions (between 15 and $60 \mathrm{~km}$ from the fires). Most of the 11 stations measured $\mathrm{PM}_{10}$ (particular matter less than $10 \mu \mathrm{m}$ in diameter) but not $\mathrm{PM}_{2.5}$ concentrations at hourly intervals. ANOVA was used to test whether $\mathrm{PM}_{10}$ and $\mathrm{PM}_{2.5}$ levels were elevated at each monitor during the fire (up to 18:00) or in the night (18:00-10:00 the following morning) compared to the full record (from 00:01 9 October 2015 to 23:59 10 October 2015).

5. Visual observations of the fires were made from a suitable vantage point $(920 \mathrm{~m}$ from the $52 \mathrm{ha}$ fire and $4.5 \mathrm{~km}$ away from the 700 ha fire), consisting of the vertical angle of the top of the plumes (measured using a clinometer) and compass bearings for the top, left and right side of the plumes.

6. Radar data from the Bureau of Meteorology rain radar at Appin (approximately $5 \mathrm{~km}$ from the fires) was examined using the 3-D Rapic visualisation program (Purdham, 2007). The data consist of reflectance values for radial pixels of 14 "slices" at different vertical tilt angles from the radar. The software can display a 3-D pro- 

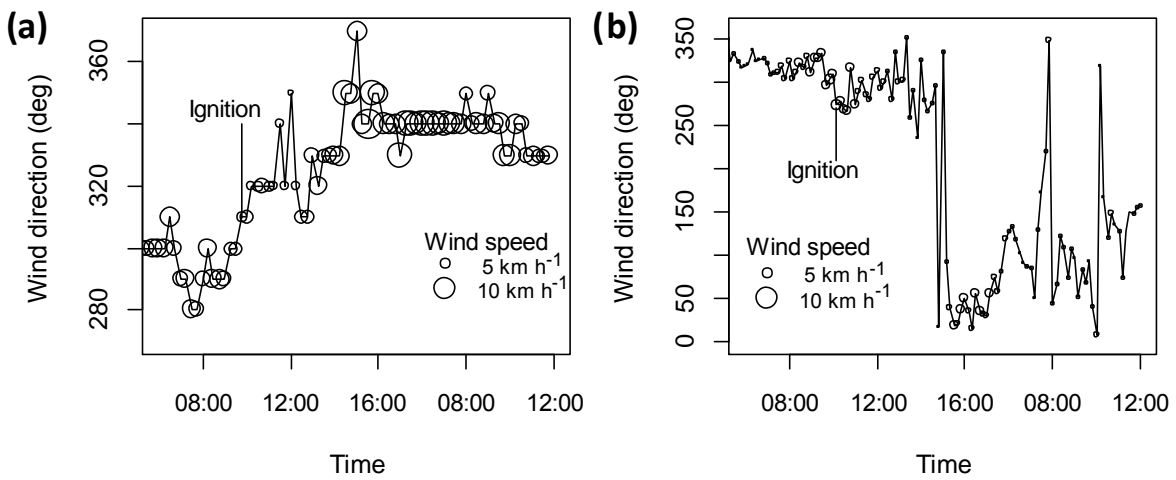

Figure 3. Wind direction and speed recorded during the fires: (a) from Lucas Heights for the 52 ha fire and (b) from the mobile weather station for the 700 ha fire.

file (e.g. cross section or planar view) of the plume at 6 min intervals during the day. Rain radar has been used in several studies to measure the vertical and horizontal spread of wildfire smoke (Jones and Christopher, 2010; Cruz et al., 2012; Fromm et al., 2012). However, radar detects objects at least $100 \mu \mathrm{m}$ in diameter, so it measures larger particles in the smoke than the $\mathrm{PM}_{2.5}$ fractions recorded by the other instruments. The data were used to produce a series of polygons outlining the extent of the plumes at several times of the day.

7. An automatic weather station was located inside the fire for the 700 ha fire. It was not deployed for the 52 ha fire so measurements from a permanent meteorological station at Lucas Heights ( $24 \mathrm{~km}$ northeast of the fire) were used (Bureau of Meteorology, unpublished data). In addition, upper atmospheric data were sourced for the Sydney Airport weather station (Bureau of Meteorology, unpublished data), $46 \mathrm{~km}$ from the fires, from which the $\mathrm{C}$-Haines index of atmospheric instability (Mills and McCaw, 2010) was calculated for 07:00 local time. This index and its precursor (the Haines index) have been shown to be correlated with extreme fire behaviour, and in particular with the development of huge pyro-cumulous smoke plumes (Mills and McCaw, 2010).

8. Smoke plume predictions were generated by the $\mathrm{Ru}-$ ral Fire Service smoke forecasting system $24 \mathrm{~h}$ before the proposed burn. The smoke forecasting system couples the TAPM (a commonly used air quality dispersion model in Australia; Hurley et al., 2005) with CCAM (a weather forecasting model; Engelbrecht et al., 2009; McGregor, 2015). The system uses forecast weather up to 5 days before the fire with an assumed injection of smoke at a height of $1000 \mathrm{~m}$ and produces predicted grids of $\mathrm{PM}_{2.5}$ concentrations with $1 \mathrm{~km}$ resolution, for 18 vertical strata $(10-8000 \mathrm{~m})$ at hourly intervals until $24 \mathrm{~h}$ after the fire. The Rural Fire Service system applies a standard equation from the National Pollutant Inventory (1999) to convert the area and fuel load of the fire into an emission rate and duration entered into TAPM. The correlation coefficient was calculated between predicted hourly values at $10 \mathrm{~m}$ elevation and actual readings from four locations near the fires.

9. Some supplementary data were also obtained from carbon monoxide monitors near the entrance of shafts at two nearby coal mines operated by a mining company.

\section{Results}

\subsection{Calibration of the DustTrak monitor}

The 13 calibration points taken when the portable (handheld) monitor was co-located with the reference monitor spanned a range from 4 to $221 \mathrm{\mu g} \mathrm{m}^{-3}$ recorded on the reference monitor and 18 to $1163 \mu \mathrm{g} \mathrm{m}^{-3}$ on the portable monitor. The calibration provided a correction factor of 0.223 for the portable monitor (i.e. it overestimated $\mathrm{PM}_{2.5}$ levels by nearly a factor of 5), with a Pearson correlation coefficient $(r)$ of 0.834 .

\subsection{Plume characteristics}

The 52 ha fire was complete by approximately 17:00. The wind direction (at Lucas Heights) was $300^{\circ}$ (north-westerly) at ignition and gradually swung to $340^{\circ}$ (northerly) until 15:00 when it remained stable until midnight. Wind speed was generally moderate $\left(5-15 \mathrm{~km} \mathrm{~h}^{-1}\right)$ (Fig. 3a). The maximum ambient air temperature was $26.7^{\circ} \mathrm{C}$ and the minimum relative humidity was $33 \%$ (at 15:20) on the day. The CHaines index (Mills and McCaw, 2010) of atmospheric instability at 07:00 at Sydney Airport was 6.33 (which is the 80th percentile value for the index at that station; Bureau of Meteorology, unpublished data), indicating a relatively unstable atmosphere. Visual observations estimated that the plume developed about $30 \mathrm{~min}$ after ignition and gradually grew to its maximum height of approximately $460 \mathrm{~m}$ at $12: 30$, thereafter 
(a)

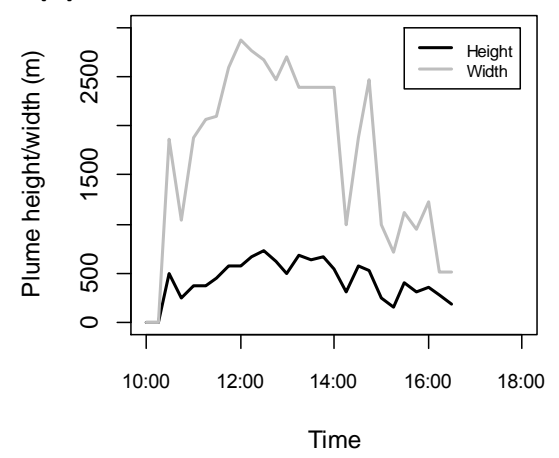

(b)

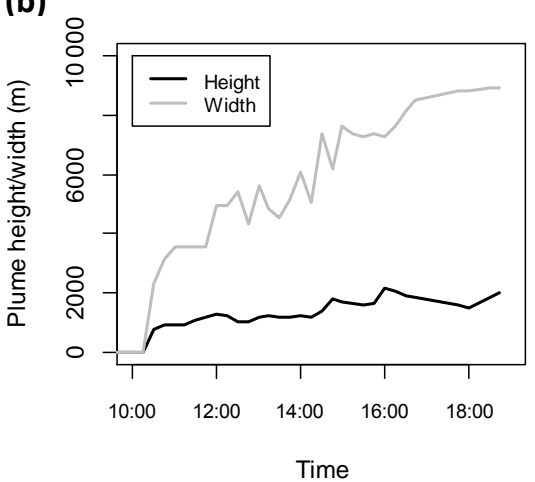

Figure 4. Visual observations of the development of plume height and width for (a) the 52 ha fire and (b) the 700 ha fire.

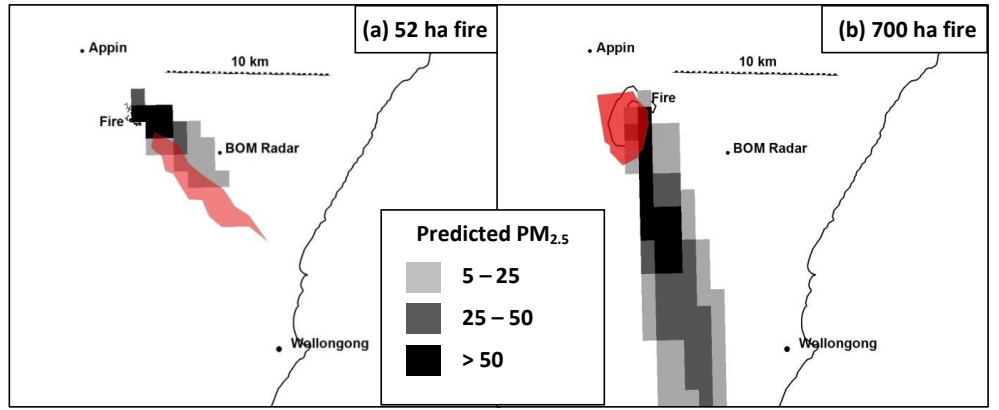

Figure 5. Smoke plumes for the each fire as observed from the 3-D radar data at noon and predicted surface $\mathrm{PM}_{2.5}$ concentrations from the dispersion model. The pink shading is the outline recorded from the rain radar.

gradually reducing to be less than $200 \mathrm{~m}$ by $16: 30$ (Fig. 4a). The width peaked at $3900 \mathrm{~m}$ at 12:00. The rain radar data detected a plume extending southeast to a maximum of $9 \mathrm{~km}$ (peaking at 11:24, Fig. 5a). The maximum plume height recorded from the rain radar was $900 \mathrm{~m}$ at 13:34.

The 700 ha fire produced a plume that was higher, far more extensive and lasted longer than the 52 ha fire. Smoke was still rising at 18:45 (near sunset). Aerial incendiaries were dropped within the burnt-out perimeter at about 16:00 to ensure the completion of the burn within 1 day. The wind at the fire ground was light and variable, being westerly at the ignition time and shifting to north-easterly toward 15:00, and never exceeding $5 \mathrm{~km} \mathrm{~h}^{-1}$ for the data collection period (Fig. 3b). Maximum ambient air temperature was $28.1^{\circ} \mathrm{C}$ and minimum relative humidity was $36 \%$ on the day (similar conditions to the 52 ha fire). The 07:00 C-Haines index was -0.95 (the seventh percentile value), indicating a very stable atmosphere. The plume was visible almost immediately and built gradually to a height of $\sim 1000 \mathrm{~m}$ at 13:00 (Fig. 4b). The plume grew rapidly at $14: 45$ to $1400 \mathrm{~m}$ altitude and then again at 15:45 to $2200 \mathrm{~m}$ (probably resulting from the aerial incendiaries). The plume remained in the same general location, to the south of the fire, but gradually expanded all day to reach a maximum visual width of $8.5 \mathrm{~km}$. Notably, from about 14:30, a section of the plume above $\sim 1000 \mathrm{~m}$ altitude began to spread north. The general size and location of the plume in the early hours was confirmed by the rain radar, which detected a relatively stable, circular plume above and slightly to the south of the fire with a diameter of $\sim 6 \mathrm{~km}$ (Fig. 5b). The height of the plume observed on radar was $1000 \mathrm{~m}$ for most of the day, with a significant boost in the late afternoon, reaching a maximum height of $2000 \mathrm{~m}$ at 16:48.

\subsection{Pollution measurements}

The two reference air quality monitors near the fires showed wide fluctuations in pollutant levels which were partially in synch with each other (Fig. 7a, b, Table 1). In both fires, $\mathrm{PM}_{2.5}$ concentrations reached $>900 \mu \mathrm{g} \mathrm{m}^{-3}$ at the western monitor while the fire was alight, but less than $400 \mu^{-3} \mathrm{~m}^{-3}$ at the eastern monitor. Night-time peaks were observed at both monitors in both fires, at about midnight for the 52 ha fire and 04:00 for the 700 ha fire (Fig. 7a, b). In both cases, the concentrations were $\sim 200 \mu \mathrm{g} \mathrm{m}^{-3}$. Light rain fell on the fire ground at about 06:00 on 23 August, and no pollution was detected from the $52 \mathrm{ha}$ fire after this. Average $24 \mathrm{~h}$ concentrations at the western and eastern reference monitors were 117 and $101 \mu \mathrm{g} \mathrm{m}^{-3}$ respectively for the 52 ha fire and 122 and $34 \mu \mathrm{g} \mathrm{m}^{-3}$ for the 700 ha fire (Table 1). 
Table 1. Locations for particulate monitor readings, along with the maximum $\mathrm{PM}_{2.5}$ reading, time of that reading and $24 \mathrm{~h}$ average value. Locations other than the reference monitors were estimated assuming value of $4 \mu \mathrm{g} \mathrm{m}^{-3}$ for non-observed periods.

\begin{tabular}{|c|c|c|c|c|c|c|c|c|c|c|c|}
\hline \multirow[t]{2}{*}{ Location } & \multirow{2}{*}{$\begin{array}{c}\text { ID } \\
\text { (see map) }\end{array}$} & \multirow{2}{*}{$\begin{array}{l}\text { Easting } \\
\text { (m) }\end{array}$} & \multirow{2}{*}{$\begin{array}{l}\text { Northing } \\
\text { (m) }\end{array}$} & \multicolumn{4}{|c|}{52 ha fire } & \multicolumn{4}{|c|}{700 ha fire } \\
\hline & & & & $\begin{array}{c}\text { Reading } \\
\text { count }\end{array}$ & $\begin{array}{c}\text { Max } \\
\mathrm{PM}_{2.5}\end{array}$ & $\begin{array}{c}\text { Time } \\
\text { of max }\end{array}$ & $\begin{array}{c}24 \mathrm{~h} \\
\text { mean }\end{array}$ & $\begin{array}{c}\text { Reading } \\
\text { count }\end{array}$ & $\begin{array}{c}\text { Max } \\
\mathrm{PM}_{2.5}\end{array}$ & $\begin{array}{c}\text { Time } \\
\text { of max }\end{array}$ & $\begin{array}{c}24 \mathrm{~h} \\
\text { mean }\end{array}$ \\
\hline Eastern reference monitor & 1 & 299739 & 6208372 & 240 & 372.3 & 11.15 & 100.7 & 240 & 871 & 11.05 & 122.4 \\
\hline Western reference monitor & 2 & 299293 & 6208941 & 240 & 1105 & 15.10 & 116.7 & 240 & 200 & 11.4 & 33.6 \\
\hline North & 3 & 300321 & 6208976 & 12 & 13.2 & 14.00 & 4.59 & 13 & 35.1 & 15.25 & 5.1 \\
\hline Dead & 4 & 299976 & 6208379 & 16 & 1006 & 13.40 & 209.7 & 11 & 66.1 & 11.15 & 8.3 \\
\hline Gate & 5 & 299784 & 6208251 & 13 & 531.5 & 14.07 & 78.1 & 15 & 164.8 & 11.17 & 19.0 \\
\hline Pole 16 & 6 & 299428 & 6207880 & 11 & 862.6 & 14.51 & 51.5 & 14 & 195.9 & 11.55 & 22.3 \\
\hline Pole 13 & 7 & 298951 & 6207849 & 11 & 195.8 & 14.54 & 22.1 & 11 & 216.2 & 14.09 & 23.6 \\
\hline South & 8 & 298534 & 6207849 & 11 & 13.4 & 14.18 & 4.94 & 15 & 752.1 & 10.57 & 40.9 \\
\hline Cataract Road & 10 & 298258 & 6208293 & 0 & & & & 4 & 275.4 & 14.05 & 18.9 \\
\hline
\end{tabular}

The handheld monitor showed high $\mathrm{PM}_{2.5}$. concentrations at downwind locations close to both fires (with no smoke pollution upwind), but the patterns at each location differed between the fires because the 700 ha fire was further from the monitoring locations and the wind tended to be slightly more northerly (Fig. 7c, d). Several locations close to the 52 ha fire recorded peak concentrations $>500 \mu \mathrm{g} \mathrm{m}^{-3}$ and 24 average concentrations $>50 \mu \mathrm{g} \mathrm{m}^{-3}$ (Table 1). Only one location recorded concentrations $>500 \mu \mathrm{g} \mathrm{m}^{-3}$ in the 700 ha fire, and none had average 24 values $>50$ (Table 1 ).

A survey further afield revealed that a shroud of smoke from the 700 ha fire had settled in the catchment of the Cataract Dam to the south of the fire, with accompanying high $\mathrm{PM}_{2.5}$ concentrations, including a 1 min reading of $45 \mathrm{\mu g} \mathrm{m}^{-3}$ at Mount Keira (14 km south of the fire) at 14:38. There was also a smoke haze in Wollongong, which may have been due to the fire (though no readings were taken there). The rain radar did not detect this southward spread of ground-level smoke. A survey along roads in the evening revealed an obvious shroud of wildfire smoke and high concentrations approximately $4 \mathrm{~km}$ west of the fire $\left(108 \mu \mathrm{g} \mathrm{m}^{-3}\right.$ at 18:51 at 550 Wilton Road, $89 \mu \mathrm{g} \mathrm{m}^{-3}$ at 18:55 at Broughton Pass (see Fig. 1). A revisit to the fire area on the morning of 10 October found low $\mathrm{PM}_{2.5}$ concentrations in the immediate vicinity of the fire, but high concentrations at more distant locations northwest of the fire, including $169 \mu \mathrm{g} \mathrm{m}^{-3}$ at Appin Colliery (08:40) and $37 \mu \mathrm{g} \mathrm{m}^{-3}$ in Appin town centre at 08:42. An obvious shroud of smoke was present at the Belltree Kennels $5.5 \mathrm{~km}$ north of the fire, recording $157 \mu \mathrm{g} \mathrm{m}^{-3}$ (09:02) while at Copperfield road on the southern end of Campbelltown (12 km north of fire) the reading was $52 \mu \mathrm{g} \mathrm{m}^{-3}$ (09:06) (Fig. 1). Concentrations in central Campbelltown were lower (21.0 and $7.4 \mu \mathrm{g} \mathrm{m}^{-3}$ at Hyde Park and the freeway intersection respectively).

Particulate data from the regional air quality network confirmed that smoke from the 700 ha fire had settled at ground layer in several distant areas at different times (Fig. 6, Table 2). It is difficult to isolate a smoke effect in the PM signal

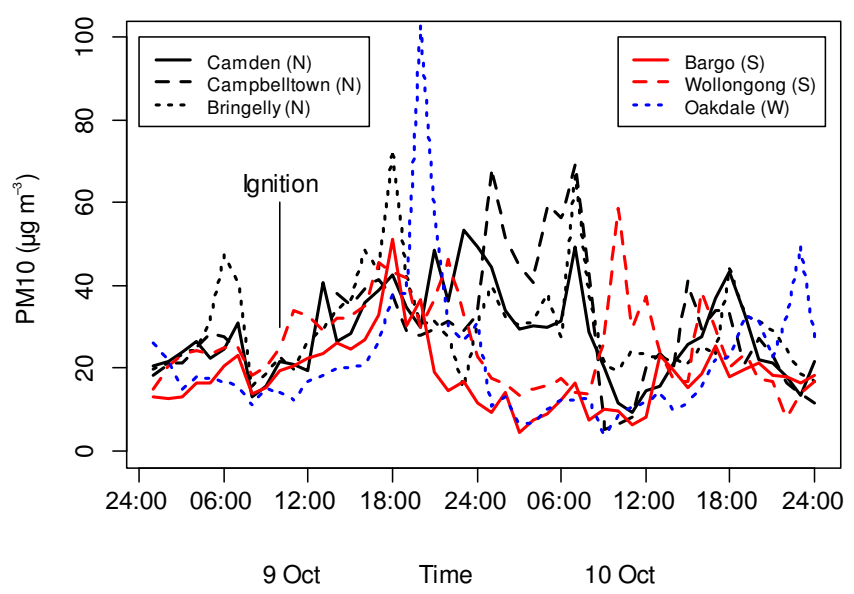

Figure 6. Trace of $\mathrm{PM}_{10}$ measurements for the 700 ha from the Office of Environment and Heritage permanent air quality network. See also Table 2 for statistical analysis.

from these permanent monitors because several of them have high urban background concentrations that fluctuate during the day. Nevertheless, a combination of the presence of sudden peaks and statistical comparison of periods showed that monitors to the south of the fire (Wollongong and Bargo) had significantly elevated PM levels during the fire (which may be a normal, smoke-free pattern), the monitor to the west had a sudden spike at 20:00 (Oakdale, peak PM $_{10}$ level $=102.9 \mu \mathrm{g} \mathrm{m}^{-3}$ ), and monitors to the north (Camden, Campbelltown and Bringelly) had greatly elevated levels later during the night when the other monitors returned to low levels (Fig. 6). No other fires were reported in the region to explain these peaks (S. Chadwick, personal communication, 2015). Monitors even further north in Sydney also showed significantly elevated values at night, but these were lower than those in Campbelltown and Camden. The $24 \mathrm{~h}$ average PM concentrations were much lower than the peaks (last column in Table 2), with none of the $\mathrm{PM}_{2.5}$ monitors sus- 
Table 2. Summary of particulate observations from the permanent air quality network. The data are the mean values in four periods: before the 700 ha fire (midnight 9 October 2015 - 10:00), during the fire (10:00-18:00), during the night (18:00-06:00 10 October 2015) and the following day (10:00-18:00). "Raised during" and "Raised at night" report ANOVA tests comparing two particular periods to all the others. $P$ values are reported $\left(*: p<0.05,^{* * *}: p<0.001\right)$.

\begin{tabular}{|c|c|c|c|c|c|c|c|c|}
\hline \multicolumn{2}{|c|}{ Monitor (measure) } & \multirow{2}{*}{$\begin{array}{l}\begin{array}{l}\text { Before } \\
\text { fire }\end{array} \\
16.1\end{array}$} & \multirow{2}{*}{$\begin{array}{l}\begin{array}{l}\text { During } \\
\text { fire }\end{array} \\
24.6\end{array}$} & \multirow{2}{*}{$\begin{array}{l}\begin{array}{l}\text { Post-fire } \\
\text { night }\end{array} \\
17.0\end{array}$} & \multirow{2}{*}{$\begin{array}{l}\begin{array}{l}\text { Following } \\
\text { day }\end{array} \\
17.1\end{array}$} & \multirow{2}{*}{ 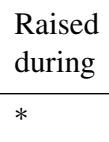 } & \multirow{2}{*}{$\begin{array}{l}\text { Raised } \\
\text { at night }\end{array}$} & \multirow{2}{*}{$\begin{array}{l}\begin{array}{l}24 \mathrm{~h} \\
\text { mean }\end{array} \\
19.5\end{array}$} \\
\hline \multirow{3}{*}{ South of fire } & Bargo_PM 10 & & & & & & & \\
\hline & Wollongong_PM 10 & 21.7 & 33.3 & 25.3 & 24.6 & $*$ & - & 28.0 \\
\hline & Wollongong_PM 2.5 & 6.9 & 7.8 & 10.7 & 8.1 & - & - & 9.8 \\
\hline West of fire & Oakdale_PM 10 & 17.5 & 18.7 & 25.8 & 21.5 & - & - & 23.4 \\
\hline \multirow{6}{*}{ North of fire } & Camden_PM 10 & 22.2 & 29.1 & 37.0 & 22.3 & - & $* * *$ & 34.5 \\
\hline & Camden_PM 2.5 & 11.8 & 8.2 & 24.1 & 11.3 & - & $* * *$ & 18.8 \\
\hline & Campbelltown_PM 10 & 23.8 & 38.5 & 41.1 & 22.0 & - & $* * *$ & 40.6 \\
\hline & Bringelly_PM 10 & 27.1 & 32.8 & 36.0 & 25.2 & - & $*$ & 34.9 \\
\hline & Liverpool_PM $_{10}$ & 23.5 & 32.7 & 35.8 & 24.6 & - & $* * *$ & 34.8 \\
\hline & Liverpool_PM 2.5 & 12.0 & 4.5 & 22.2 & 11.0 & - & $* * *$ & 16.3 \\
\hline \multirow{6}{*}{ City of Sydney } & Chullora_PM 10 & 22.7 & 25.7 & 28.8 & 24.0 & - & $*$ & 27.8 \\
\hline & Chullora_PM 2.5 & 11.1 & 6.0 & 12.5 & 11.6 & - & - & 10.3 \\
\hline & Earlwood_PM $_{10}$ & 22.9 & 24.4 & 28.6 & 25.3 & - & $*$ & 27.2 \\
\hline & Earlwood_PM 2.5 & 9.0 & 6.7 & 11.2 & 11.4 & - & - & 9.8 \\
\hline & Randwick_PM 10 & 21.3 & 27.8 & 25.8 & 20.3 & $*$ & $*$ & 25.4 \\
\hline & Rozelle_PM 10 & 23.3 & 24.8 & 26.1 & 23.6 & - & - & 25.7 \\
\hline
\end{tabular}

tained levels above $25 \mu \mathrm{g} \mathrm{m}^{-3}$ and none of the $\mathrm{PM}_{10}$ monitors above $50 \mathrm{\mu g} \mathrm{m}^{-3}$. Supplementary carbon monoxide data from two mines showed a strong peak at Appin $(2 \mathrm{~km}$ northwest of the fire) from 11:30 lasting until 09:00 (maximum level $15.0 \mathrm{ppm}, 24 \mathrm{~h}$ mean $3.9 \mathrm{ppm})$ and at Westcliff $(500 \mathrm{~m}$ north) between 02:30 and 04:30 (maximum level 11.5 ppm, $24 \mathrm{~h}$ mean 1.7) (Fig. 7e). It seems that smoke affected the ground level in downwind directions probably as far as Wollongong $(15 \mathrm{~km})$ during the fire, and the fire also generated a large plume which collapsed overnight affecting places as far as $30 \mathrm{~km}$ from the fire, beginning before 19:00 to the west of the fire and after midnight to the north.

Inspection of the aerological diagrams for 06:00 and 16:00 at Sydney Airport suggests that smoke was capped by an inversion layer at about $1300 \mathrm{~m}$ all day with a complex wind shear developing in the afternoon around the boundary layer below the inversion (S. Louis, personal communication, 2015). This atmospheric condition may have been responsible both for the northerly spread of the lofted air and the subsequent collapse to the surface.

\subsection{Comparison with the smoke plume predictions}

As shown in Fig. 5, the smoke plume forecasting system predicted the surface smoke (as $\mathrm{PM}_{2.5}$ ) to spread downwind much as it actually occurred for the first several hours of each fire. However, the model predicted some northward spread of surface smoke that did not occur. For the 52 ha fire, the model predicted that $\mathrm{PM}_{2.5}$ concentrations would continue to rise until 15:00 (peaking at $111 \mathrm{\mu g} \mathrm{m}^{-3}$ ) and remain above $25 \mu \mathrm{g} \mathrm{m}^{-3}$ in areas up to $7 \mathrm{~km} \mathrm{SE}$ of the fire until 20:00 before reducing and shifting to the northeast of the fire by midnight (predictions for noon are shown in Fig. 5). The correlation between predicted and actual values was 0.559 at the east monitor, 0.222 at the west monitor, 0.396 at the "North" location and -0.092 at "Pole 16". The ratio (predicted / actual) of values at the four locations ranged from 0.15 to 9.8 (large under-estimate to large overestimate).

For the 700 ha fire, the model predicted ground level $\mathrm{PM}_{2.5}$ concentrations to be high in a narrow plume to the south of the fire, remaining above $25 \mu \mathrm{g} \mathrm{m}^{-3}$ at distances up to $12 \mathrm{~km}$ away until 17:00, much as has actually happened (though both the visual observation and the rain radar indicated that the majority of the plume remained near the fire). By 19:00, predicted concentrations had reduced to below $25 \mu \mathrm{g} \mathrm{m}^{-3}$ in all places and had become wider (less directional). By 23:00, predicted concentrations were everywhere below $1 \mu \mathrm{g} \mathrm{m}^{-3}$, whereas in reality the plume was collapsing by this time with high concentrations in many areas. The Pearson correlation between observed and predicted values was high at both reference monitors $(r=0.867$ and 0.646$)$ and "Pole $16 "(r=0.679)$. However, there was low correlation at the "North" site $(r=0.340)$. The ratio (predicted / actual) of values at the four locations ranged from 0.13 to 2.9. 
(a)

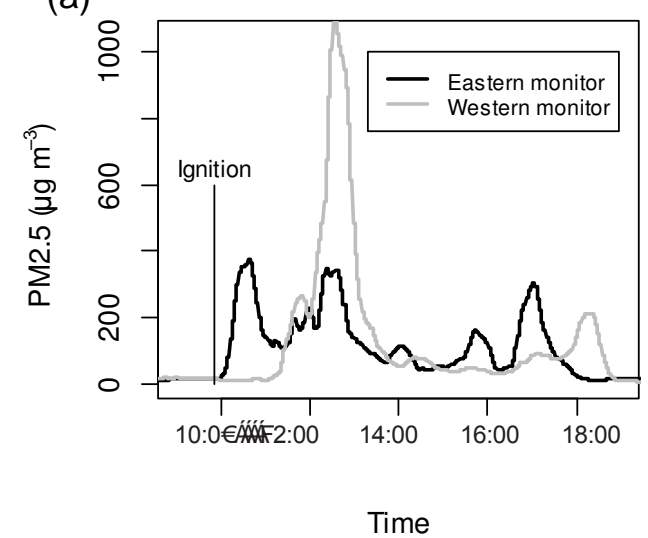

(c)

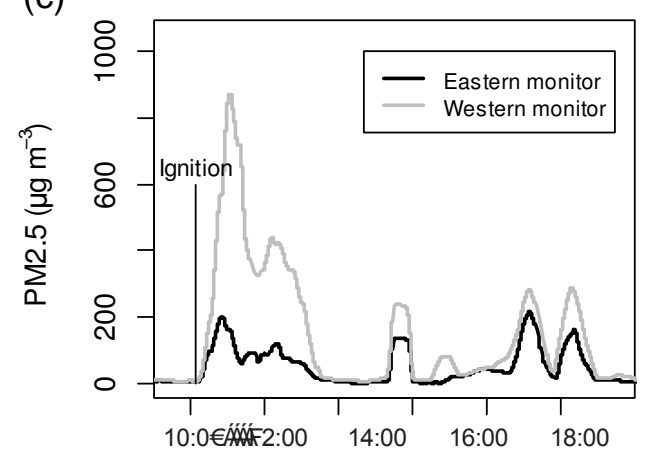

Time (b)

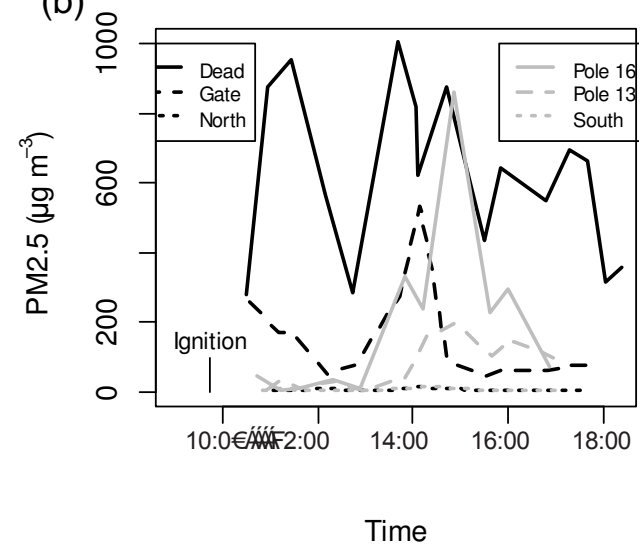

(d)

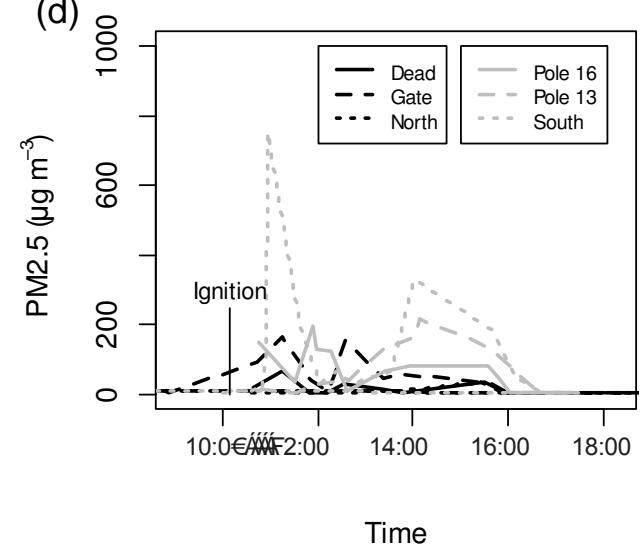

(e)

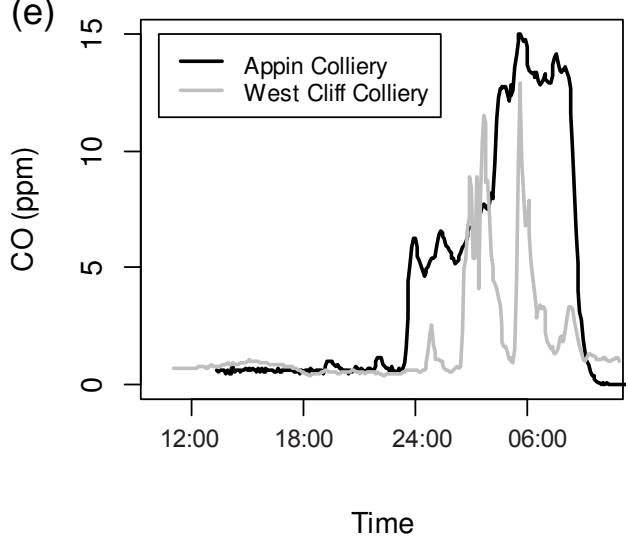

Figure 7. Time traces of air pollutants during the fires: (a) $\mathrm{PM}_{2.5}$ measured at the reference monitors for the 52 ha fire and (b) 700 ha fire; (c) $\mathrm{PM}_{2.5}$ measured by handheld monitor at different locations in the 52 ha fire and (d) 700 ha fire; and (e) $\mathrm{CO}$ concentrations measured at two mine entrances during the 700 ha fire.

\section{Discussion}

The data from these two fires demonstrates that the smoke impact from prescribed fires can be severe. Peak $\mathrm{PM}_{2.5} \mathrm{lev}$ els $>1000 \mu \mathrm{g} \mathrm{m}^{-3}$ and $24 \mathrm{~h}$ average levels of $209 \mu \mathrm{g} \mathrm{m}^{-3}$ were recorded at one location $100 \mathrm{~m}$ away from the 52 ha fire and other locations up to $500 \mathrm{~m}$ downwind from that fire also recorded very high levels (e.g. Gate, peak 531, 24,

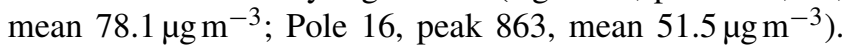
The $\mathrm{PM}_{2.5}$ levels during the fire are similar to those found by Pearce et al. (2012) at similar distances to prescribed burns in savanna vegetation, including their peak value of $180 \mu \mathrm{g} \mathrm{m}^{-3} \sim 9 \mathrm{~km}$ from one of the fires. Four locations near the $52 \mathrm{ha}$ fire and three near the 700 ha fire recorded $24 \mathrm{~h}$ av- 
erage $\mathrm{PM}_{2.5}$ above the national standard $\left(25 \mu \mathrm{g} \mathrm{m}{ }^{-3}\right.$ for average daily $\mathrm{PM}_{2.5}$ exposure). The 700 ha fire generated generally lower peaks and sustained PM levels but spread lowlevel pollution over a huge area. This large-scale impact is the most novel finding from this study. Relatively low $24 \mathrm{~h}$ average levels at the permanent network of monitors suggested that this pollution was not a serious health hazard, but individual $1 \mathrm{~min} \mathrm{PM}_{2.5}$ readings from the handheld monitor above $150 \mu \mathrm{g} \mathrm{m}^{-3}$ at some locations on the morning after the fire indicate that it might have been a localised hazard in certain areas.

The larger fire lofted more smoke to a higher elevation and spread pollution over a much larger area than the smaller fire. The aerial incendiaries which rapidly increased the size of the larger fire were probably partly responsible for the higher plumes in that fire. However, it is difficult to compare the local impact of the fires $(\sim 500 \mathrm{~m}$ from the fire) because the distance and bearing of the monitors to the fire were different between the fires and the wind was blowing from a slightly different direction. The data show higher local $\mathrm{PM}_{2.5}$ levels in the 52 ha fire, but this may simply be because the monitors were closer or more directly downwind than in the 700 ha fire. The atmosphere was much more stable in the larger fire (as reflected in the C-Haines index values) and also the winds were lighter. This presumably explains why the larger fire plume was trapped under an inversion layer during the night and possibly why shear caused some of the smoke to spread northward against the surface wind direction during the afternoon. The fact that the $700 \mathrm{~m}$ fire lofted smoke to approximately twice the height of the 52 ha was presumably because it generated more convective energy as opposed to any atmospheric effect (we would have expected the more stable air to limit the lofting height). The rapid increase in plume height at the time of the aerial incendiaries confirms this interpretation. The higher plume in the 700 ha fire will counter the fact that a greater total amount of smoke was produced to ameliorate the local smoke concentrations but only to a limited extent. Pearce et al. (2012) found a positive relationship between fire size and PM concentrations (range of fire sizes 10-1100 ha).

The atmospheric dispersion model predicted the distribution and concentration of pollution accurately during the daylight hours of both fires, but failed in three important respects. First, it did not capture the fine-scale variation in PM concentrations that is important when predicting local impacts. This is partly because of the coarse resolution of the model ( $1 \mathrm{~km}$ pixels), but it may also reflect poor representation of the ambient wind or even the interaction between the wind and the fire itself. Second, the model failed to predict the northward spread of lofted smoke in the 700 ha fire in afternoon, though it did predict smoke spread at higher elevation to be different to the surface spread. Third, it failed to predict high PM concentrations during the night as a result of a temperature inversion.
This study is a preliminary attempt to apply empirical techniques to quantify the air quality impact of prescribed fires and the accuracy of a smoke prediction system. Many more fires would need to be studied before a systematic picture of the impacts of prescribed fires can be developed. Research should focus on (1) understanding the spatial scale of the smoke hazard from prescribed fires; (2) understanding when and why they can have bad outcomes; and (3) further testing of the atmospheric dispersion models. This kind of research is difficult because it requires equipment and personnel to be on "standby" for a planned fire. The fires used in this project were postponed 12 times (including one abandoned altogether). The reference monitors need to be deployed 2 days before the fire to enable calibration, and final notification that burns will proceed often do not allow this amount of time. One shortcut method that could be used would be a historical analysis of $\mathrm{PM}_{2.5}$ data from the permanent air quality network, looking at days when known prescribed fires were lit nearby one of the monitors, assuming such events did occur.

We acknowledge that the uncertainty in the $\mathrm{PM}_{2.5}$ concentrations provided by the DustTrak monitor. In this study, it was found that the monitor overestimated the reference values by almost a factor of 5 . DustTraks are commonly used for field $\mathrm{PM}_{2.5}$ measurements (Innis, 2013), and overestimation by a factor of 1.7 and 2.2 times the reference are reported (Trent, 2006; McNamara et al., 2011). Hence, the overestimation in this study still appears high.

\section{Conclusion}

This study found particulate pollution levels to exceed national air quality standards in the vicinity of two prescribed fires, suggesting that local residents would be strongly impacted. Low-level impact occurred over a very large area $\left(1200 \mathrm{~km}^{2}\right)$ from the larger (700 ha) fire, and in some lowlying places this may have caused an exceedance. The large area affected was possibly caused by a combination of two effects: wind shear causing smoke to spread against the surface wind direction and a temperature inversion at night that caused smoke to collapse to the ground. The TAPM smoke dispersal model predicted the general behaviour of the plumes in the early hours, but not the counter-wind spread or the collapse of the plume.

It is likely that these findings are general: high local impact and a risk of regional low-level impact, increasing with the size of the prescribed fire. However, many more fires would need to be studied to be confident of these conclusions.

Agencies that conduct prescribed fires should aim to improve their prediction of smoke behaviour to minimise the air quality impacts on local communities. 


\section{Data availability}

Air quality data for the portable stations and handheld monitors, the visual plume observations, and the radar-derived plume outlines will be deposited at an approved site (currently under negotiation with University of Wollongong). Carbon monoxide, weather and simulated plume data were supplied by external agents and are not publicly available. They can be supplied under licence in the first instance by contacting the authors.

Acknowledgements. Many people and organisations contributed to this project: in particular, Phil Purdam for analysing 3-D rain radar data; Laurence McCoy, David Field and Stuart Chadwick from the Rural Fire Service (RFS) of NSW for logistical support; Stuart Mathews and Simon Louis (also RFS) for providing weather data and smoke plume predictions; John Kirkwood, Gunashanhar Gunaratnam and Bradley White from the NSW Office of Environment and Heritage for deploying and operating the reference air quality monitors; Garry Duncan from Appin Colliery for CO data; and Clare Murphy from the University of Wollongong for advice and the loan of equipment. This study was funded by the Rural Fire Service NSW and by ARC Linkage grant no. LP130100146.

Edited by: B. D. Malamud

Reviewed by: two anonymous referees

\section{References}

Adetona, O., Simpson, C. D., Onstad, G., and Naeher, L. P.: Exposure of Wildland Firefighters to Carbon Monoxide, Fine Particles, and Levoglucosan, Ann. Occup. Hyg., 57, 979-991, 2013.

Boer, M. M., Sadler, R. J., Wittkuhn, R., McCaw, L., and Grierson, P. F.: Long-term impacts of prescribed burning on regional extent and incidence of wildfires - evidence from fifty years of active fire management in SW Australian forests, Forest Ecol. Manag., 259, 132-142, 2009.

Bradstock, R. A., Cary, G. J., Davies, I., Lindenmayer, D. B., Price, O., and Williams, R. J.: Wildfires, fuel treatment and risk mitigation in Australian eucalypt forests: insights from landscape-scale simulation, J. Environ. Manage., 105, 66-75, 2012.

Cruz, M. G., Sullivan, A. L., Gould, J. S., Sims, N. C., Bannister, A. J., Hollis, J. J., and Hurley, R. J.: Anatomy of a catastrophic wildfire: The Black Saturday Kilmore East fire in Victoria, Australia, Forest Ecol. Manag., 284, 269-285, 2012.

Engelbrecht, F. A., McGregor, J. L., and Engelbrecht, C. J.: Dynamics of the Conformal-Cubic Atmospheric Model projected climate-change signal over southern Africa, Int. J. Climatol., 29, 1013-1033, 2009.

Fromm, M. D., McCRae, R. H. D., Sharples, J. J., and Kablick III, G. P.: Pyrocumulonimbus pair in Wollemi and Blue Mountains National Parks, 22 November 2006, Australian Meteorological and Oceanographic Journal, 62, 117-126, 2012.

Haikerwal, A., Reisen, F., Sim, M. R., Abramson, M. J., Meyer, C. P., Johnston, F. H., and Dennekamp, M.: Impact of smoke from prescribed burning: Is it a public health concern?, JAPCA J. Air Waste Ma., 65, 592-598, 2015.
Hanigan, I. C., Johnston, F. H., and Morgan, G. G.: Vegetation fire smoke, indigenous status and cardio-respiratory hospital admissions in Darwin, Australia, 1996-2005: a time-series study, Environ. Health-UK, 7, 42, doi:10.1186/1476-069X-7-42, 2008.

Hurley, P. J., Physick, W. L., and Luhar, A. K.: TAPM: a practical approach to prognostic meteorological and air pollution modelling, Environ. Modell. Softw., 20, 737-752, 2005.

Innis, J.: BLANkET1 Technical Report 22, Burn Brighter 2012, and smoke surveys in Tasmania 2010-2012, Air Section, Tasmanian Environment Protection Agency, Hobart, 2013.

Jayachandran, S.: Air Quality and Early-Life Mortality Evidence from Indonesia's Wildfires, J. Hum. Resour., 44, 916-954, 2009.

Johnston, F., Hanigan, I., Henderson, S., Morgan, G., and Bowman, D.: Extreme air pollution events from bushfires and dust storms and their association with mortality in Sydney, Australia 19942007, Environ. Res., 111, 811-816, 2011.

Jones, T. A. and Christopher, S. A.: Satellite and Radar Remote Sensing of Southern Plains Grass Fires: A Case Study, J. Appl. Meteorol. Clim., 49, 2133-2146, 2010.

Keith, D. A.: Ocean shores to desert dunes: The native vegetation of New South Wales and the ACT, Department of Environment and Conservation, Hurstville, NSW, 2004.

Lavdas, L. G.: Program VSMOKE User's Manual, USFS Southern Research Station, Asheville, NC, 147 pp., 1996.

McGregor, J. L.: Recent developments in variable-resolution global climate modelling, Climatic Change, 129, 369-380, 2015.

McNamara, M. L., Noonan, C. W., and Ward, T. J.: Correction factor for continuous monitoring of wood smoke fine particulate matter, Aerosol Air Qual. Res., 11, 315-322, 2011.

Meyer, C. P., Lee, S., and Cope, M.: Smoke impacts from prescribed burning in Victoria, developing a risk climatology, 20th International Congress on Modelling and Simulation, Adelaide, Australia, 1-6 December 2013, 200-206, 2013.

Mills, G. and McCaw, L.: Atmospheric Stability Environments and Fire Weather in Australia - extending the Haines Index, Centre for Australian Weather and Climate Research, Melbourne, 151 pp., 2010.

Miranda, A. I., Martins, V., Cascao, P., Amorim, J. H., Valente, J., Tavares, R., Borrego, C., Tchepel, O., Ferreira, A. J., Cordeiro, C. R., Viegas, D. X., Ribeiro, L. M., and Pita, L. P.: Monitoring of firefighters exposure to smoke during fire experiments in Portugal, Environ. Int., 36, 736-745, 2010.

National Pollutant Inventory: Emissions estimation technique manual for aggregated emissions from prescribed burning and wildfires, Environment Australia, Canberra, 1999.

Pearce, J. L., Rathbun, S., Achtemeier, G., and Naeher, L. P.: Effect of distance, meteorology, and burn attributes on ground-level particulate matter emissions from prescribed fires, Atmos. Environ., 56, 203-211, 2012.

Price, O. F. and Bradstock, R. A.: Quantifying the influence of fuel age and weather on the annual extent of unplanned fires in the Sydney region of Australia, Int. J. Wildland Fire, 20, 142-151, 2011.

Price, O. F., Williamson, G. J., Henderson, S. B., Johnston, F., and Bowman, D. J. M. S.: The relationship between landscape fire activity from Modis Hotspots and particulate pollution levels in Australian cities, Plos One, 7, e47327, doi:10.1371/journal.pone.0047327, 2012. 
Price, O. F., Pausas, J. C., Govender, N., Flannigan, M., Fernandes, P. M., Brooks, M. L., and Bird, R. B.: Global patterns in fire leverage: the response of annual area burnt to previous fire, Int. J. Wildland Fire, 24, 297-306, 2015.

Purdham, P. J.: 3D-Rapic - The Australian radar visualisation system, 33rd American Meteorological Society Conference, American Meteorological Society, Cairns, Australia, 2007.

Reisen, F. and Brown, S. K.: Impact of prescribed fires on downwind communities, Proceedings of the Royal Society of Queensland, Special Edition: Bushfire 2006 Conference, 115, 85-91, 2009.

Reisen, F., Hansen, D., and Meyer, C. P.: Exposure to bushfire smoke during prescribed burns and wildfires: Firefighters' exposure risks and options, Environ. Int., 37, 314-321, 2011.
Sapkota, A., Symons, J. M., Kleissl, J., Wang, L., Parlange, M. B., Ondov, J., Breysse, P. N., Diette, G. B., Eggleston, P. A., and Buckley, T. J.: Impact of the 2002 Canadian forest fires on particulate matter air quality in Baltimore City, Environ. Sci. Technol., 39, 24-32, 2005.

Tham, R., Erbas, B., Akram, M., Dennekamp, M., and Abramson, M. J.: The impact of smoke on respiratory hospital outcomes during the 2002-2003 bushfire season, Victoria, Australia, Respirology, 14, 69-75, 2009.

Trent, A.: Smoke particulate monitors: 2006 update, US Department of Agriculture, Missoula, MT, USA, 15 pp., 2006. 